\title{
Integrated Analysis of CO2 Emission Intensity, Bilateral FDI, and Institutional Quality Nexus: Case Study of $\mathbf{G 2 0}$ Countries
}

\section{Prajukta Tripathy}

National Institute of Technology Rourkela

Monalisa Khatua

National Institute of Technology Rourkela

Pragyanrani Behera

National Institute of Technology Rourkela

Lopamudra D. Satpathy

Sushilavati Government Women's College Rourkela, Sundargarh, India

\section{Pabitra Kumar Jena}

Shri Mata Vaishno Devi University

Bikash Ranjan Mishra ( $\nabla$ bikashranjan.mishra@gmail.com )

National Institute of Technology Rourkela

\section{Research Article}

Keywords: CO2 emission intensity, Bilateral FDI, Institutional quality, Panel data, Simultaneous techniques, $\mathrm{G} 20$ countries

Posted Date: November 10th, 2021

DOl: https://doi.org/10.21203/rs.3.rs-935774/v1

License: (c) (i) This work is licensed under a Creative Commons Attribution 4.0 International License.

Read Full License 


\section{4}

\section{Prajukta Tripathy}

Research Scholar, Department of Humanities and Social Sciences, National Institute of Technology Rourkela, India.

Email: prajukta.chinu@gmail.com

\section{Monalisa Khatua}

Research Scholar, Department of Humanities and Social Sciences, National Institute of Technology Rourkela, India. Email: khatuamonalisa98@gmail.com

\section{Pragyanrani Behera}

Research Scholar, Department of Humanities and Social Sciences, National Institute of Technology Rourkela, India. Email: beherapragyanrani@gmail.com

\section{Lopamudra D. Satpathy}

Assistant Professor, Department of Economics

Sushilavati Government Women's College, Rourkela, Sundargarh, India. Email: satpathy.lopa@gmail.com

\section{Pabitra Kumar Jena}

Assistant Professor, School of Economics, Shri Mata Vaishno Devi University, Katra (Jammu \& Kashmir), India. Email: pabitrakumarjena@gmail.com

\section{Bikash Ranjan Mishra*}

*Corresponding Author

Assistant Professor, Department of Humanities and Social Sciences,

National Institute of Technology Rourkela, India.

Email: bikashranjan.mishra@gmail.com; Mob: +91-7894516320 
44 A clean natural environment is a primary concern of contemporary lives, business investments, and governments.

45 However, there is a lack of knowledge of how countries can achieve high investment across borders and better 46 institutional quality while protecting the environment. Thus the current paper explores the effect of bilateral FDI, 47 institutional quality, and $\mathrm{CO}_{2}$ emission intensity on each other for 19 selected G20 countries over the 2009-2017 48 periods. This paper estimates the three equations that jointly address the endogeneity problem by employing both 49 static and dynamic simultaneous econometrics techniques with a panel dataset. The empirical results confirm that 50 bilateral FDI reduces $\mathrm{CO}_{2}$ emission intensity and strengthens the institutional quality in G20. The results also 51 support a positive and significant effect of institutional quality on bilateral inward FDI and $\mathrm{CO}_{2}$ emission intensity. 52 This paper confirms a positive and considerable feedback effect of $\mathrm{CO}_{2}$ emission intensity on institutional quality. 53 Further, this study establishes a triplex relationship between these three factors and consolidates vital policy insights 54 to achieve sustainable growth concerning the nexus among environment quality-FDI-institution quality for G20 55 economies.

56 Keywords: $\mathrm{CO}_{2}$ emission intensity, Bilateral FDI, Institutional quality, Panel data, Simultaneous techniques, G20 57 countries

58 JEL Classification Q53, Q56, F21, F23, Q28, E02

59

60

61

62 


\section{Introduction}

72 The increasing level of $\mathrm{CO}_{2}$ emission is a pertinent issue and is widely discussed in different policy frameworks.

73 According to Intergovernmental Panel on Climate Change (2014), $\mathrm{CO}_{2}$ emission is a significant anthropocentric

74 contributor to environmental degradation, which has reached approximately $1^{0} \mathrm{C}$ and resulted in extreme weather

75 events, rising sea levels, and melting of Arctic sea ice. This will lead to long-term and irreversible changes such as

76 destruction of the ecosystem, increased ocean acidity, extreme weather events like more frequent and severe natural

77 disasters. All together causes severe negative economic and social impacts such as increased poverty, inequalities

78 with high food insecurity, and ill worsening peoples' safety and health directly affecting humans' lives (United

79 Nations 2019). Therefore, an increase in $\mathrm{CO}_{2}$ emission is a hazard and a premier concern of every economy

80 globally. The majority of $\mathrm{CO}_{2}$ emission comes from industrialization and fossil fuel combustion; those are consistent

81 components of economic growth and development (Sabir et al. 2020). At the same time, industrialization is the base

82 for any investment and economic growth and development. However, years ago, economists proposed an 'inverted

83 U' shaped relationship between economic growth and environmental quality, commonly known as the environmental

84 Kuznets curve (EKC) (Grossman and Krueger 1991). The well-investigated EKC hypothesis has different

85 distinguished mechanisms by which investment from foreign sources like foreign direct investment (FDI) can affect

86 the environmental quality.

87 Nevertheless, inward FDI has many contributions, such as employment creation, productivity enhancement,

88 diffusion of technologies, human capital formation, and internationalization and economic integration (Sabir et al.

89 2020). However, the policymakers believed that the host countries need to improve their institutional quality

90 performances to attract more FDI inflows (Ullah and Khan 2017). In addition, Bokpin (2017) has explained that

91 better institutional quality characterized by stable governance, well-developed democracy, and control of a country's

92 corruption is necessary for an economy to accrue more FDI inflows. However, FDI is not free from the negative

93 consequences of environmental quality (Opoku and Boachie 2020), and thus the FDI-environment quality nexus

94 remain under surveillance for all countries. On the one hand, researchers argued that FDI leads to sustainable

95 economic growth with cleaner and advanced technologies in host countries (Abdouli et al. 2018). On the contrary,

96 studies claimed that FDI harms environment quality and causes $\mathrm{CO}_{2}$ emission through polluting industries (Omri et

97 al. 2014; Shahbaz et al. 2015). This argument mainly supports that FDI contributes to economic prosperity with the

98 additional cost of environmental degradation.

99 In this line, studies highlighted that the polluting multinational firms invest in countries with inadequate and less

100 stringent environmental regulations or economies with poor institutional qualities (Sabir et al. 2020). From this, it

101 can be assessed that the polluting multinational firms invest in countries with inadequate and less stable regulations.

102 Therefore, this puts a strong rationale for institutional quality in protecting the environmental quality from the

103 polluting units. Thus, developed institutional quality is not only helped to attract more FDI inflows but also restrict

104 the polluting firms from entering the host countries' environment (Dang 2019; Mahjabeen et al. 2020). However,

105 few studies have addressed such nexus among FDI-institution-environment and attempted to examine such a

106 multiplex relationship among these three variables (Dang 2019; Sabir et al. 2020). They argued that a better 
institutional quality could boost environment-friendly FDI and set the host countries' environmental quality. Thus, it becomes imperative to examine the bidirectional and the triplex relationship among environmental quality, bilateral FDI, and institutional quality, which are more or less ignored in the existing studies. Therefore, this study attempts to examine this nexus among $\mathrm{CO}_{2}$ emission intensity-bilateral FDI-institutional quality in the case of selected G20 economies.

Our paper has the following objectives: (1) to verify the "pollution halo" or "pollution haven" hypothesis for bilateral FDI on $\mathrm{CO}_{2}$ emission intensity and the existence of the reverse effect of $\mathrm{CO}_{2}$ emission intensity on bilateral FDI. (2) To explore whether the institutional quality will increase or decrease $\mathrm{CO}_{2}$ emission intensity and verify the reverse impact of $\mathrm{CO}_{2}$ emission intensity on institutional quality. (3) To examine the role of institutional quality on FDI and know the feedback effect of FDI on institutional quality. (4) To empirically explore the trilateral relationship among $\mathrm{CO}_{2}$ emission intensity, bilateral FDI, and institutional quality in a simultaneous framework.

The novelties of this study are sevenfold. First, it investigates the simultaneous nexus among FDI-institutionenvironment. Second, we use bilateral FDI data and include other host and source countries' bilateral characteristic variables. Third, instead of taking only the developing or the developed countries, this paper considers a mixed group of countries (G20) to present the heterogeneity and balanced picture of the world. Fourth, we used a comprehensive coverage dataset for 19 selected G20 countries, considering host and source countries with 342-panel pairs from 2009 to 2017. We use the IMF's newly available bilateral FDI data. Fifth, this analysis remained safe from the omission biased after controlling the significant macroeconomic variables. Sixth, we covered a wide range of institutional quality indicators following Kunčič (2014) for our empirical estimation. Finally, this study minimizes the gap concerning econometric modeling using static and dynamic system models such as seemingly unrelated regression, three-stage least square, and generalized method of moments. According to empirical analysis, our research put forward some specific policy implications for reducing $\mathrm{CO}_{2}$ emission and achieving more FDI inflows with better institutional qualities in selected G20 countries.

The rest of this study is organized as follows. In section 2, a structured review and hypotheses are provided. In section 3, the data, variables, and methods are explained. In section 4, the empirical results and discussion are described. Section 5 presents the conclusion, and policy implications are described in section 6.

\section{Literature Review}

This section considers four-part links between environment quality, bilateral FDI, and institutional quality of 135 existing literature.

\subsection{Environmental quality and FDI}

137 The theoretical literature on environment-FDI nexus is better explained with four different hypotheses: the Porter 138 Hypothesis (PH, henceforth), the Pollution Haven Hypothesis (PHH, henceforth), the Race-to-Bottom Hypothesis 139 (RTB, henceforth), and the Pollution Halo Hypothesis (PHHH, henceforth). The Porter hypothesis states that FDI 
comes with new and advanced technology and can improve the host countries' environmental quality (Porter and

141 Van der Linde 1995). Therefore, with new and greener technologies, investors use less energy-intensive capital and cause fewer emissions (Mielnik and Goldemberg 2002). In contrast, the literature on PHH started by Pething (1976)

143 explains that the pollution-intensive production units migrate from more stringent environmental regulation

144 (developed/North) countries to less stringent regulated (developing/south) countries to minimize the cost of adhering

145 to these regulations. Copeland and Taylor (1994) have mentioned that the flight of polluted industries using FDI

146 towards growing economies provides economic opportunities but brings environmental hazards in the long run. This

147 hypothesis also gives a branch to another hypothesis called 'race to the bottom' in developing countries. That allows

148 polluting units from developed nations to developing countries and brings global pressure on the environment

149 (Rudolph and Figge 2017). Contrary to the PHH and the RTB hypotheses, the PHHH hypothesis argues that FDI in developing countries improves economic development and provides green and advanced technologies, thus improving environmental quality (Zarsky 1999). The argument lies that FDI is coming from developed economies, then it is more eco-friendly with greener technologies. Thus FDI not only generates economic growth but also improves the host countries' environment quality. Clubbing all the theoretical arguments on environmental qualityFDI nexus, two approaches can be well addressed. First, FDI has a negative relationship with environmental quality. The second approach argues a positive relationship between FDI and environment quality.

The existing empirical literature of FDI-environment quality nexus has examined a positive and significant relationship between FDI and $\mathrm{CO}_{2}$ emission. It supports the PHH hypothesis for developed countries (like Kuwait, Turkey), for many developing and growing countries (like Mexico, Brazil, India, and China), and for a set of Asian developing countries (Acharyya 2009; Jun et al. 2018; Salahuddin et al. 2018; Khan and Ozturk 2020). In contrast, recent studies highlighted that FDI and environmental quality have a positive association. This supports the PHHH and the PH hypothesis for different developed and developing countries like Malaysia, and China, 30 OECD countries, MINT groups, and a set of Sub-Sharan African countries (Pazienza 2015; Acheampong et al. 2019; Balsalobre-Lorente et al. 2019). In addition, considering a different set of countries, Shahbaz et al. (2015) and Marques and Cantano (2020) highlighted that the PHH exists only for low and middle-income countries and is rejected for high-income countries. However, there are minimal studies available on the reverse effect of environmental quality on FDI. According to Walter and Ugelow (1979), environmental quality significantly affects the international capital moment. In this regard, the contemporary literature evidence that the environment is an essential input factor of production, and thus the environment has a significant effect on socio-economic activities (Pao and Tsai 2011; Azam 2016). However, Haug and Ucal (2019) denied any significant relationship between FDI and environmental quality and argued that FDI variation could not explain environmental regulations.

\section{2.2. Environmental quality and Institutional quality}

172 The theoretical base for environmental quality-institutional quality nexus is well explained in two critical theories:

173 the environmental governance theory (EGT) and the ecological modernization theory (EMT). The EGT theory is 174 applied to determine the crucial factors influencing environmental outcomes and their objectives (Baron and Lyon 175 2012). This theory helps institutions to mitigate environmental externalities. Thus the EGT theory argues that 
governance of an economy is the fundamental factor to create efficient environment management and helps to

177 improve the environment quality (Armitage et al. 2012). Second, the EMT theory emphasizes the relationship

178 between environmental deterioration and social, political, and institutional changes (Mol and Spaargaren 2000).

179 Unlike EGT, EMT systematically analyzes how economic, political, and social forces interact with one other in

180 providing environmental goods and services (Lemprière 2016).

181 In this regard, a good number of empirical literature have demonstrated the relationship between institutional quality 182 and quality of the environment and gained various researchers' attention. Different economists have used specific 183 institutional quality indicators (for example, democracy, political globalization, and control of countries' corruption) 184 in case of the EU, G20, BRICS, and OECD countries (Paramati et al. 2017; Wang et al. 2018). They highlighted a negative relationship between institutional quality and environmental degradation and concluded that better institutional quality improves better environmental quality. In contrast, Scruggs and Rivera (2008) have mentioned that democracy and political freedom have no significant role in better environmental quality. However, with different institutional indicators, the outcomes are forced to remain contradictory and lead to an insufficient solution. Therefore, it is wise to take composite indicators of institutional quality instead of single indicators to keep studies from remaining inconclusive as institutional quality components usually interact (Wu 2017). The relationship between institutional quality indices and $\mathrm{CO}_{2}$ emissions has drawn much attention to overcome this limitation. Using a bunch of institutional parameters from World Development Indicators (WDI), International Country Risk Guide (ICRG), and Freedom Index dataset, existing studies examined in several cross country studies (for instance, BRICS, MENA, EMDEs, and many different sets of developing countries). They found that institutional quality has a significant role in improving the environmental quality (Wu 2017; Ali et al. 2019; Danish et al. 2019; Azam et al. 2020; Le and Ozturk 2020; Omri and Mabrouk 2020). These studies' findings commonly support that an influential institution can improve environmental quality in developed and developing economies. In contrast, Armenien and Mengaki (2019) highlighted no significant effect of institutional quality changes on $\mathrm{CO}_{2}$ emission in 67 high-income and upper-middle-income countries. However, there is hardly any study available that measures the role of environmental quality to determine the host countries' institutional quality.

\subsection{FDI and Institutional quality}

202

A growing body of literature has examined MNCs' location decisions through the institutional lens and explains two theories supporting institutional quality have a significant role in determining FDI inflows. According to Dunning (1980), a multinational corporation (MNCs) enters host countries to capture ownership, location, and internalization advantages. This is also known as the eclectic paradigm or the OLI model. After Dunning, the institutional economist North (1990) has pioneered the theory of 'institution' and set the rules of games those MNCs should follow in their own experience and optimal resource allocation. In return, host countries' government must improve their institution to lower the transaction costs to encourage foreign investors. In addition to these two theories in recent times, Westney (1993) has explored the feedback effect of FDI on the host country's institutional quality. The study revealed that MNCs significantly improve the host countries' organizational patterns through subsidiaries. In 
211 summary, it can be assumed that the theoretical view highlighted that better institutions are positively related to FDI

212 inflows, and more FDI can improve the host countries' institutional quality.

213 The empirical literature on these theoretical arguments emphasizes the effects of different institutional dimensions

214 (like property rights protection, control of corruption, democracy, government stability, civil liberty, and political

215 rights) on inward FDI. It revealed that foreign investors are incredibly motivated by the host country's institutions

216 (Aziz 2018; Ibrahim et al. 2020). However, recent studies revealed that the coefficients of control of corruption,

217 government effectiveness, political stability, the rule of law, and the voice and accountability significantly attract

218 FDI inflows in developed countries but do not impact FDI inflows in developing countries substantially (Peres et al.

219 2018; Sabir et al. 2019). At the same time, recent literature constructed the composite institutional indicators

220 considering its importance to examine the diversified influence of institutional indicators on inward FDI (Moon

221 2019). In this regard, a set of empirical literature have examined the FDI-institutional quality indices nexus for a

222 group of developing regions (Kurul and Yatra 2017; Ullah and Khan 2017). They put a similar conclusion that better

223 institutional quality can significantly attract more FDI inflows in those regions. In contrast, Kandil (2009) revealed

224 that institutional quality is not significant in attracting FDI inflows. On the other side, some recent studies have

225 explored the positive role of FDI inflows on institutional quality and revealed that FDI inflow could stimulate host

226 countries' institutional quality improvement (Fukumi and Nishijima 2010; Huynh 2020; Huynh et al. 2020).

227 On the other hand, this detailed literature is mainly based on unidirectional FDI inflows, and the number of studies

228 exploring the nexus from bilateral FDI stock is minor. Thus, these studies mostly neglect the host and source

229 approach to deal with the destination's FDI and institutional quality nexus. To emphasize this importance, Daude

230 and Stein (2007) and Kunčič and Jaklič (2014) used bilateral FDI stocks from OECD countries worldwide and

231 suggested that institutions greatly influence FDI stocks. In recent times, Mishra and Jena (2019) also found that a

232 composite institutional index plays a vital role in attracting FDI in major Asian countries. However, hardly any

233 study examines FDI-institutional quality nexus with bilateral FDI and composite institutional quality index in G20.

\section{2.4. Environmental quality, FDI, and Institutional quality}

235 Two common concepts can establish theoretical connections on the trilateral relationship between FDI, institutional quality, and environmental quality: environmental governance theory and the pollution haven hypothesis. These theories mainly argue a strong relationship with institutions, open economy, and environmental degradation (Adeola 2000). More specifically, Sabir et al. (2020) highlighted that the level of $\mathrm{CO}_{2}$ emission could be controlled with stringent rules and regulations. The stringent regulations also influence inward FDI and their external effect on the host countries' environmental quality.

241 Recent studies have highlighted the role of institutional defects and their cruciality while judging the environmental

242 effects of FDI (Tang et al. 2020). Considering this, Wang et al. (2020) mentioned that corruption indirectly leads to 243 pollution by lowering the existing standards, enabling low-quality FDI inflow, and weakening the FDI spillover

244 effect. Similarly, it is argued that democracy plays a significant role in influencing FDI and natural resources. 
Further, good institutional quality is an instrument to reduce the adverse effect of environmental quality on FDI (Asiedu 2013; Dang 2019). Therefore, good governance is an instrument to meet the environmental challenges related to inward FDI (Bokpin 2017). On the contrary, Jorgenson (2009) demonstrated that less-developed countries could not minimize the harmful effects of FDI on the environment even after solid government regulations.

The existing studies have explained the nexus among environment quality, FDI environment quality, and institutional quality. However, the empirical results are mixed (see Table 1.), and the conclusions are elusive. Although the studies already signified the environmental quality and FDI relationship, further investigation on bidirectional relations in the G20 context is less evidenced. Next, concerning the choice of institutional quality indicators, only a few papers have covered a comprehensive coverage of its indicators (see Kunčič 2014), while the study does not have coverage for environmental quality. The next gap lies as hardly any composite institutional index verifies bidirectional effect with bilateral FDI in G20. Finally, as per the best of our knowledge, only one study (Dang 2019) has examined a trilateral linkage between environmental quality, bilateral FDI, and governance indicators. Therefore, to minimize such a massive gap in this FDI-institution-environment relation, we draw a new analysis to reveal the relationship correctly in selected G20 countries. By considering the importance of this nexus, the study follows the following hypotheses:

$H_{1}$ : There is a bidirectional relationship between bilateral FDI stocks and $\mathrm{CO}_{2}$ emission intensity.

$\mathrm{H}_{2}$ : There is a bidirectional relationship exist between institutional quality and $\mathrm{CO}_{2}$ emission intensity.

$H_{3}$ : There is a bidirectional relationship between bilateral FDI and institutional quality.

$H_{4}$ : There is a simultaneous relationship exist between environmental quality, bilateral FDI, and institutional quality.

\section{Data, Variables, and Methods}

This section focuses on the analysis of the data and variables and econometric techniques used in this study.

\subsection{Data Description and Data Source}

This study examines the impact of $\mathrm{CO}_{2}$ emissions intensity, bilateral FDI, and institutional quality on each other for 2009-2017 of G20 countries excluding the European Union (EU). Our study employs data of G20 countries as a sample for our estimation because it covers the world's major economies, where G20 comprises major developed economies such as G7 countries and typically the most emerging countries such as BRICS (Yao and Tang 2020). According to the IMF (2017), the economic performance of G20 members together contributed around $90 \%$ of the gross world product. They comprise approximately two-thirds of the world's population, and about $80 \%$ contribution to world trade. At the same time, the ratio of $\mathrm{CO}_{2}$ emissions from $\mathrm{G} 20$ countries to world $\mathrm{CO}_{2}$ emissions over decades has remained a significant issue started from 1970 to now (Mardani et al. 2018). However, studies relating to the environmental quality of G20 countries are highly explored but mainly limited to energy-growth-environment linkages (Li et al. 2020; Xu et al. 2020). Simultaneously, hardly any study has covered such a triplet association 
considering $\mathrm{CO}_{2}$ emission intensity, bilateral FDI, and institutional quality. However, the EU has not been included in our country selection because it is based on the country-level data, but the EU comprises 28 countries. Another reason is that some countries (such as France, Germany, Italy, and the UK) also stand individually in the G20 groups. Thus, it is better to prevent the EU in our cross-country list (Wang et al. 2018). The survey periods in the econometric models are limited to 2009-2017 because of two reasons. First, the upper limit is restricted to show the importance of the global financial crisis when the G20 responded to several coordinated economic policies and aimed for 'strong, sustainable and balanced growth' at the Pittsburg Summit 2009. The second significant restriction to this period is the availability of IMF data for bilateral FDI. All data are collected from different sources. For more straightforward analysis, variables are transformed into a natural logarithm form, and in the case of variables with zero and negative values, we follow Gujarati (2004) method. Variables used in the empirical estimation with the measurement, definition, source, and expected signs are reported in Table 2. The variables' descriptive statistics of this paper are reported in Table 3.

\subsubsection{Dependent variables}

Three dependent variables of our empirical estimation are $\mathrm{CO}_{2}$ emission intensity, bilateral FDI, and institution. The first dependent variable of our estimation is $\mathrm{CO}_{2}$ emission intensity $\left(\mathrm{CO}_{2}\right) \cdot \mathrm{CO}_{2}$ emission is used globally due to its data on the most extended panel among other global and local pollutants to measure the environmental performance. However, as $\mathrm{CO}_{2}$ is only a byproduct of energy consumption, it becomes viable to take $\mathrm{CO}_{2}$ intensity $\left(\mathrm{CO}_{2} /\right.$ energy use) as a better measure of the environment quality of countries than the level of $\mathrm{CO}_{2}$ emissions or its per capita level (Hosseini and Kaneko 2013). Thus, we take $\mathrm{CO}_{2}$ intensity measured with $\mathrm{CO}_{2}$ emissions per energy use to proxy environmental quality.

The second dependent variable we use for our empirical model is bilateral FDI stock (FDI). The advantages of stock rather than flows are: First, it is a better measure of capital ownership as local capital markets finance it. Second, stocks are less volatile than the flows (Kunčič and Jaklič 2014; Kahouli and Maktouf 2015). The bilateral FDI stock depends on the origin country i's characteristics, destination country j's characteristics, and bilateral-specific variables size of the economy and geographical distance. Following a mirror approach, we use an inward bilateral FDI position from the Coordinated Direct Investment Survey (CDIS) database compiled by the IMF for all the 19 countries from a host country perspective.

The third dependent variable of our research is the institutional quality (INST). To ease the comparison of different quality measures of the institution, we followed the approach developed by Kunčič (2014) and normalize the indicators to lie between zero and one, such that a higher number lies higher quality institutions. The institutional quality is measure through 31 formal institutional indicators. ${ }^{1}$ As a proxy for the host country's institutional functions, our research employs data from various sources to compute the institutional quality index ${ }^{2}$. The

${ }^{1}$ See Kunčič (2014) better understand formal all Institutional quality indicators (except checks and balances), standardization, computation, and their sources.

${ }^{2}$ See Table 2 for detailed sources. 
institutional quality index of this study follows a principal factor analysis and provides a single factor score for each country as such higher values reflect better institutional quality (Kunčič and Jaklič 2014).

\subsubsection{Main explanatory variables}

313 1. Market size. Studies argue that market size plays an essential role in attracting foreign investors (Aziz 2018) and 314 helps to develop an eco-friendly environment with good institutions (Wang et al. 2018). Thus, following Hargrove et 315 al. (2019), GDP per capita is a proxy for market size (DGDPPC).

316 2. Distance. Large parts of the growing empirical literature of FDI location are based on gravity. In its standard 317 specification of bilateral trade flows (in our case, bilateral inward FDI stocks) depends negatively on the distance 318 between them (Daude and Stein 2007). The empirical estimation employs distance (DIST ANCE) and it is measured with the great circle geographical gap between the countries' capitals.

3. Financial Development. Researchers argue that defining financial development is one of the vital pillars of FDI and the better institution of host economies (Donaubauer et al. 2020). In this paper, private credit has been considered a proxy to measure our empirical estimation's financial development $(F D)$.

4. Trade openness. The degree of openness is a significant factor in stimulating FDI and the institutional frame of an economy (Aziz 2018). In addition, Hargrove et al. (2019) mentioned trade openness as a significant factor influencing the level of $\mathrm{CO}_{2}$ emission. Following the previous literature (Essandoh et al. 2020), our study uses total export and import of goods and services as a percentage of GDP (TRADE) to measure trade openness.

5. Natural resource endowment. Most FDI has invested in countries endowed with natural resources, including oil, natural gas, and minerals. However, a transparent relationship between the institution and natural resources endowment potentially motivates FDI and also determines the level of $\mathrm{CO}_{2}$ emission intensity (Sabir et al. 2020; Hosseini and Kaneko 2013). Considering its importance, we use natural resource depletion (\% of Gross National Income) as a proxy to natural resource endowment (RESOURCE).

6. Inflation. A high rate of inflation may be costlier for foreign investors with high uncertainties. Thus, it becomes crucial to judge the institutional quality of any country that is responsible for long-term unsustainability concerning price setting and profit expectations (Khan and Hanif 2020). We consider the annual percentage of GDP deflator as a proxy of inflation (INFL) in our estimation.

7. Infrastructure. A developed infrastructure such as internet services is vital to attract FDI, establish better governance, and improve the environmental quality (Kahouli and Omri 2017). Following Kahouli and Maktouf (2015), our study uses individuals using the internet (\% of the population) as a proxy to infrastructure development (INF).

8. Population. The size of an economy's population shows the size of the economy and has a more significant influence on foreign direct investment (Kahouli and Maktouf 2015). However, a growing population might cause 
342 more volatile institutions and become the prime cause of the rapid increase of pollution globally (Hargrove et al.

343 2019). Considering its priority, our paper accounts for the total number of residents in a nation as a proxy to the size 344 of the population $(P O P)$.

9. Human capital. Human capital is one of the significant bedrock of any country's development and helps to adopt new advanced technologies, provides better experience and skill, and motivates better environment quality (Dong et al. 2019). Following Kahouli and Maktouf (2015), we proxy the tertiary enrollment rate for human capital (HC).

10. Urbanization. Urbanization can foster a better environmental performance by tackling the climate change issue as urbanized people are more aware of the environment (Yao et al. 2018). This paper considers the urban population as a percentage of the total population $(U R B)$ as a proxy to assess the impact of urbanization on the carbon intensity level.

11. Other explanatory variables. We consider three essential variables from a bilateral approach to emphasize both host and source countries' differences and similarities to examine the nexus among environment-FDI-institution. Following Kahouli and Omri (2017), our study considers the difference in GDP per capita (DGDPPC), the difference in $\mathrm{CO}_{2}$ emission intensity $\left(\mathrm{DCO}_{2}\right)$, and the difference institutional quality index (DINST) as three core control variables in the models.

\subsection{Econometric Strategy}

358 This section explains both static and dynamic simultaneous techniques employed in our empirical estimations.

\section{$359 \quad$ 3.2.1. Static models}

Three different panel static models, such as random effect (RE), fixed effect (FE), and Hausman-Taylor regressions (HT), are used in this paper. The advantage of the random effect mechanism considers the time series and the dataset's cross-transversal nature (Kahouli and Maktouf 2015). The RE technique accounts for the interception as random variables through common member countries. However, the RE estimates become biased and inconsistent when the specific effects of the models are correlated with some explanatory variables (Kahouli and Omri 2017). Therefore, it is necessary to do the Hausman test to identify the essential bias in the estimations. If the test statistics reject the null hypothesis, the analysis prefers the FE method over the RE. The advantage of the FE estimator lies in that it helps each group member to examine different country-specific intersections (Kahouli and Omri 2017). Still, it becomes unsuitable for time-invariant variables such as distance, a fundamental variable in the bilateral FDI context (Kahouli and Maktouf 2015). To overcome this disadvantage of the FE estimator, we include the HT regression in our static models (Hausman and Taylor 1981). The HT estimates overcome the endogeneity between explanatory variables and allow time-fixed variables and time-varying variables. Some of them may be endogenous

372 in the correlation with the individual effects but exogenous to the error term. Thus it can produce consistent and

373 efficient estimates for the time-invariant variables (Kahouli and Omri 2017).

374 The three static models follow the following equation form: 


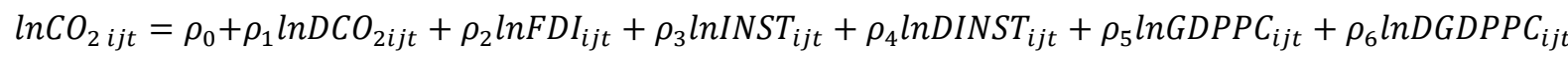

$$
\begin{aligned}
& +\rho_{7} \operatorname{lnPOP} P_{i j t}+\rho_{8} \operatorname{lnTRADE} E_{i j t}+\rho_{9} R_{\text {ESOURCE }}{ }_{i j t}+\rho_{10} \operatorname{lnINF_{ijt}}+\rho_{11} \operatorname{lnH} C_{i j t}+\rho_{12} U R B_{i j t} \\
& +\mu_{i j t} \ldots(1) \\
& \operatorname{lnFDI} I_{i j t}=\beta_{0}+\beta_{1} \operatorname{lnINST}_{i j t}+\beta_{2} \operatorname{lnDINST}_{i j t}+\beta_{3} \operatorname{lnCO}_{2, i j t}+\beta_{4} \operatorname{lnDCO}_{2 i j t}+\beta_{5} \operatorname{lnGDPPC_{ijt}} \\
& +\beta_{6} \ln D G D P P C_{i j t}+\beta_{7} \ln P O P_{i j t}+\beta_{8} \operatorname{lnF} D_{i j t}+\beta_{9} \operatorname{lnTRADE} E_{i j t}+\beta_{10} \ln R E S O U R C E_{i j t} \\
& +\beta_{11} \operatorname{lnINFL}_{i j t}+\beta_{12} \operatorname{lnINF_{ijt}}+\beta_{13} \operatorname{lnDISTANCE_{ijt}}+u_{i j t} \ldots \text { (2) } \\
& \operatorname{lnINST}_{i j t}=\alpha_{0}+\alpha_{1} \operatorname{lnDINST}_{i j t}+\alpha_{2} \operatorname{lnFDI}_{i j t}+\alpha_{3} \operatorname{lnCO}_{2 i j t}+\alpha_{4} \ln D C O_{2 i j t}+\alpha_{5} G D P P C_{i j t}+\alpha_{6} \ln D G D P P C_{i j t}
\end{aligned}
$$

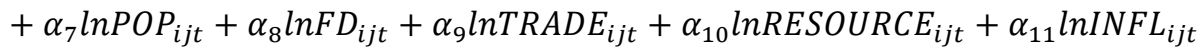

$$
\begin{aligned}
& +\alpha_{12} l n I N F_{i j t}+\epsilon_{i j t} \ldots \text { (3) }
\end{aligned}
$$

The above equations (1)-(3) are static models. Where $\mathrm{i}$ stand for host, $\mathrm{j}$ for source, $\mathrm{t}$ for time, $\rho_{0}, \beta_{0}$, and $\alpha_{0}$ are constants; $\rho, \beta$, and $\alpha$ are coefficients; $\mu_{i j t}, u_{i j t}$, and $\epsilon_{i j t}$ are the error terms in equations 1,2, and 3 , respectively.

\subsubsection{Simultaneous equations}

According to Eqs. (1), (2), and (3), the $\mathrm{CO}_{2}$ emissions intensity, bilateral FDI, and institutional quality may influence each other; therefore, there may be potential endogeneity caused by the multilateral causality. However, the conventional static estimates cannot be used here as they ignore the endogeneity and may suffer from bias and inefficient estimates (Wooldridge 2016). Therefore, we purpose of using simultaneous equation techniques in the empirical analyses.

\subsubsection{Simultaneous static equations}

The advantage of the seemingly unrelated regression (SUR) model is that it simultaneously evaluates all equations' parameters. Thus, this technique considers each equation's parameters and considers the system; then, other equations are also determined (Kahouli 2018). However, the SUR estimation is based on an assumption of no endogenous regressors and is affected by the error covariance matrix (Zellner and Thell 1962). To avoid this limitation, we use the three stages least square (3SLS) method. The 3SLS technique has the advantage of estimating all the parameters while accounts equations with endogenous regressors. Simultaneously, the 3SLS estimates are more consistent, asymptotically normal, and more efficient than single equation estimates. This research uses this technique to combine multivariate and two-stage regression (Zellner and Thell 1962). Thus, this technique improves equation-by-equation efficiency by considering correlations across equations (Wooldridge 2010).

\subsubsection{Dynamic simultaneous equations}

The three dependent variables are not free from the impacts of their lagged values independently. Thus the dynamic panel equations for our empirical estimations are as follows: 


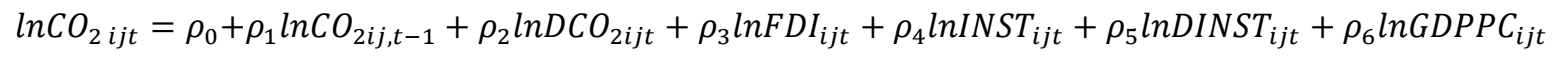

$$
\begin{aligned}
& +\rho_{7} \operatorname{lnDGDPPC} C_{i j t}+\rho_{8} \operatorname{lnPOP} P_{i j t}+\rho_{9} \operatorname{lnTRADE} E_{i j t}+\rho_{10} R E S O U R C E_{i j t}+\rho_{11} \operatorname{lnINF_{ijt}} \\
& +\rho_{12} \operatorname{lnH} C_{i j t}+\rho_{13} U R B_{i j t}+\mu_{i j t} \ldots(4) \\
& \operatorname{lnFDI}_{i j t}=\beta_{0}+\beta_{1} \operatorname{lnFDI}_{i j, t-1}+\beta_{2} \operatorname{lnINST}_{i j t}+\beta_{3} \ln D I N S T_{i j t}+\beta_{4} \operatorname{lnCO}_{2, i j t}+\beta_{5} \ln D C O_{2 i j t}+\beta_{6} \ln G D P P C_{i j t} \\
& +\beta_{7} \ln D G D P P C_{i j t}+\beta_{8} \operatorname{lnPOP} P_{i j t}+\beta_{9} \operatorname{lnFD_{ijt}}+\beta_{10} \operatorname{lnTRADE} E_{i j t}+\beta_{11} \operatorname{lnRESOURCE_{ijt}} \\
& +\beta_{12} \operatorname{lnINFL~}_{i j t}+\beta_{13} \operatorname{lnINFR}_{i j t}+\beta_{14} \operatorname{lnDISTANCE} E_{i j t}+u_{i j t} \ldots \text { (5) } \\
& \operatorname{lnINST}_{i j t}=\alpha_{0}+\alpha_{1} \operatorname{lnINST}_{i j, t-1}+\alpha_{2} \operatorname{lnDINST}_{i j t}+\alpha_{3} \operatorname{lnFDI_{ijt}}+\alpha_{4} \operatorname{lnCO_{2ijt}}+\alpha_{5} \operatorname{lnDCO} \mathrm{O}_{2 i j t}+\alpha_{6} G D P P C_{i j t} \\
& +\alpha_{7} \ln D G D P P C_{i j t}+\alpha_{8} \operatorname{lnPOP} P_{i j t}+\alpha_{9} \operatorname{lnFD_{ijt}}+\alpha_{10} \operatorname{lnTRADE} E_{i j t}+\alpha_{11} \ln R E S O U R C E_{i j t} \\
& +\alpha_{12} \operatorname{lnINFL}_{i j t}+\alpha_{13} \operatorname{lnINFR}_{i j t}+\epsilon_{i j t} \ldots(6)
\end{aligned}
$$

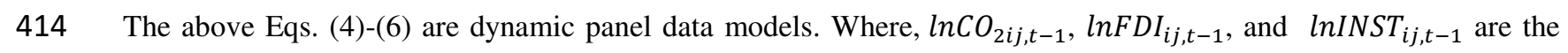
'one lagged' value of our estimation's three dependent variables, i.e., $\mathrm{CO}_{2}$ emissions intensity, bilateral FDI, and institutional quality. As per our knowledge, hardly any studies based on these three parameters are verified with such estimation considering such delayed variables. However, the introduction of dynamics in the econometric model poses serious problems due to estimators' incompatibility (Baltagi 2008). In such cases, econometric models are likely to have endogeneity problems (Muhammad and Khan 2019). We use the two-step System GMM technique (SGMM) in our estimation to fix the above issues. The SGMM helps to remove the country-pair-specific effect of the error term and the source of the correlation between the latter and lagged dependent variable (Kahouli and Maktouf 2015). This dynamic SGMM technique also overcomes the weak instrument issue is in the difference GMM (Muhammad 2019). Another advantage of this technique tackles the endogeneity issue, the data's spatial characteristics, and generates instruments from explanatory variables (Kahouli 2018). The rationale to select the two-step SGMM lies as it is considered more efficient than the one-step estimator in the case of a large sample (Khan et al. 2019). To validation the instruments of SGMM, two conditions are to be met. First, the absence of second-order autocorrelation $\left(\mathrm{AR}_{2}\right)$, and second is the over-identified hypothesis should not fail to reject in the Hansen test, which indicates that the instruments are valid and the model is correctly specified (Roodman 2009).

\section{Empirical results and discussions}

This section reports both static and simultaneous techniques' outcomes that examine the three-way linkage among environment quality, bilateral FDI, and institutional quality among G20 countries.

\subsection{Results of the static models}

435 Table 4 demonstrates estimates of the coefficients of static models such as FE and HT for $\mathrm{CO}_{2}$ emission intensity, 436 bilateral FDI, and institutional quality. However, in panel data, it is not wise to interpret simple regressions. Thus, 

rejects the null and indicates that the FE estimators are preferable to RE coefficients for our analysis; therefore, our interpretation is limited to FE results only, however, all the panel regression results (including the RE and the OLS) are shown in Table S4 (See S4A, S4B and S4C) in the supplementary material. In all static models, coefficients mostly have expected signs, and they are statistically significant. In all three cases, the F-statistics specification is statistically significant at the $1 \%$ level.

Model 1 in Table 4 demonstrates the bilateral FDI and institutional quality coefficients on $\mathrm{CO}_{2}$ emission intensity in G20 countries. The FE and the HT estimators have shown that the bilateral FDI stocks give positive coefficients but do not significantly influence $\mathrm{CO}_{2}$ emission intensity. The result demonstrates that institutional quality performance has a substantial and antagonistic relationship with $\mathrm{CO}_{2}$ emission intensity. This result is consistent with the current works' findings (Hargrove et al. 2019). Except for these two significant endogenous variables, FE and HT estimators also explain that the difference in $\mathrm{CO}_{2}$ emission intensity and the difference in institutional quality performance have a positive and significant impact on $\mathrm{CO}_{2}$ emission intensity. This shows that both countries' bilateral characteristics also affect the host countries' $\mathrm{CO}_{2}$ emissions. However, the difference in GDP per capita remains negative and insignificant. Out of the control variables, the result reveals that GDP per capita and inflation rate positively and significantly contribute to increasing $\mathrm{CO}_{2}$ emission intensity in the host countries. However, other control variables such as natural resource endowment, human capital, and urbanization negatively and significantly affect $\mathrm{CO}_{2}$ emission intensity. However, the Trade coefficient remains an insignificant factor with a negative sign for the $\mathrm{CO}_{2}$ emission intensity. The FE coefficient of the population demonstrates a negative and significant impact on $\mathrm{CO}_{2}$ emission intensity. The distance variable is considered to smoothen the HT model in Model 1; however, it remains insignificant and not affecting our results.

Model 2 presents the static model coefficients of institutional quality and $\mathrm{CO}_{2}$ emission intensity on bilateral FDI in G20. The FE and the HT estimators demonstrate that the coefficients of $\mathrm{CO}_{2}$, although negative, do not significantly influence bilateral FDI stock. Both methods' results that institutional quality positively and affect substantially host countries' inward bilateral FDI stock. This result is consistent with earlier results like (Daude and Stein 2007; Aziz

462 2018). The difference in $\mathrm{CO} 2$ emission intensity coefficient has shown a positive and significant influence on 463 bilateral FDI only in the HT model. However, the difference in institutional quality has a negative and significant 464 impact on bilateral FDI in both estimators. The coefficient of the difference GDP per capita has negatively and significantly affected the bilateral FDI. The coefficient of distance reveals a substantial and adverse effect on FDI inflows. This finding is consistent with several gravity literature of bilateral FDI (Daude and Stein 2007). The coefficient of infrastructure shows a positive and significant impact on the bilateral FDI in both techniques. This result is consistent with the existing literature (Kahouli and Maktouf 2015). In addition, the coefficient of the financial development reveals a negative and significant effect on FDI. These results support the existing findings by (Aziz 2018).

471 Model 3 reveals the static model coefficients of bilateral FDI stock and $\mathrm{CO}_{2}$ emission intensity on institutional 472 quality. According to the estimator's results, the $\mathrm{CO}_{2}$ emission intensity and the difference in the $\mathrm{CO}_{2}$ emission 
473 intensity coefficients negatively and significantly impact the host countries' institutional performances. Similarly,

474 the bilateral FDI demonstrates a significant and positive effect on the host countries' institutional performances. Our

475 finding is consistent with recent literature (Huynh 2020).

476 Similarly, the coefficients of the difference in institutional quality have a positive and significant impact on host 477 countries' institutional performances. In addition, the coefficients of the difference in GDP per capita, natural 478 resources, and inflation rate demonstrate a negative and significant impact on host countries' institutional 479 performances. The coefficient of other explanatory factors such as GDP per capita has a positive and significant 480 impact on host countries' institutional quality. The result is consistent with the existing literature (Kahouli and Omri 481 2017). The coefficient value of population demonstrates a significant and positive impact on host countries' 482 institutional qualities only in the FE. However, financial development, trade, and infrastructure coefficients remain 483 insignificant to influence the institutional quality.

[Insert Table 4 near here]

\subsection{Results of simultaneous techniques}

486 Our main models are the simultaneous estimators verified with three efficient system techniques presented in three models in Table 5. We report only the robust SGMM results and indicate the SUR and the 3SLS results with superscripts and subscripts ${ }^{3}$ if they remain significant. The two-step SGMM estimator is validated with the Hansen test and the result of the $\mathrm{AR}_{2}$ test. The statistics reported by the Hansen test indicate the acceptance of the null hypothesis that the restrictions on the identification are valid. Significantly, our $\mathrm{AR}_{2}$ results notify us that there is no second-order correlation present in any SGMM estimators.

Model 1 demonstrates the effect of bilateral FDI and institutional quality on $\mathrm{CO}_{2}$ emission intensity in G20

493 countries. The coefficient value of bilateral FDI reveals a negative and significant impact on carbon emission levels.

494 This implies that the host countries' inward FDI comes with an environmentally friendly approach and supports the 495 'halo effect.' This study is consistent with several existing literature (Dang 2019; Sabir et al. 2020). Institutional 496 quality coefficient value signifies a positive and significant effect on environmental degradation. This result implies that improvement in institutional quality deteriorates the environmental quality as a whole. This study is consistent with the empirical results of existing literature (Saidi et al. 2020).

499 The lagged carbon emission intensity coefficient value shows a significant and positive change in the carbon 500 emission level in the host countries. This implies that the current emission level has a substantial effect on the 501 environmental quality. The significant bilateral country characteristics such as difference institutional quality and 502 difference GDP per capita reveal a negative and significant association with $\mathrm{CO}_{2}$ emission intensity. This explains 503 that the higher the difference between the host and source countries' institutional performance and their economic 504 size, the lower the host countries' emission level. However, the difference in $\mathrm{CO}_{2}$ emission intensity positively and

\footnotetext{
${ }^{3}$ The SUR and the 3SLS results compared to the SGMM results are shown in Table S5 (see S5A, S5B and S5C) in the supplementary material.
} 
significantly influences the host countries' $\mathrm{CO}_{2}$ emissions. The result also reveals that the coefficient of infrastructure has a significant and negative effect on $\mathrm{CO}_{2}$ emission levels. This implies that better infrastructure facilities can help to reduce the host countries' $\mathrm{CO}_{2}$ emission intensity. Human capital's coefficient demonstrates that it is significant but negatively affects carbon emission levels. This implies that education, knowledge, and awareness about the environment can help the economy sustainably (Kahouli 2018). On the other side, urbanization shows a positive and significant impact on increasing $\mathrm{CO}_{2}$ emission intensity. This finding is consistent with the existing literature by Muhammad et al. (2020). However, the other explanatory variables like GDP per capita, population size, trade openness, and natural resource remain insignificant to influence the host countries' $\mathrm{CO}_{2}$ emissions.

Model 2 gives the simultaneous estimation coefficients of institutional quality and $\mathrm{CO}_{2}$ emission intensity impact bilateral FDI in G20 countries. The $\mathrm{CO}_{2}$ emission intensity reveals a negative and insignificant coefficient in our model. The coefficient of institutional quality indicates a positive and significant impact on inward bilateral FDI stocks. This result is consistent with the existing studies (Aziz 2018). The SGMM coefficient of the lagged value of bilateral FDI shows a positive and significant FDI in the host countries. This implies that existing bilateral FDI can substantially attract more FDI.

Similarly, the different carbon emission intensity coefficient demonstrates a significant and positive impact on bilateral FDI. This implies that a higher gap in the emission level in the two countries can promote more inward FDI into the host destinations. However, the difference in institutional quality coefficient remains negative and significant. This reveals that the similarities in institutional performances are also significant for host countries to pull more bilateral FDI into their destinations. However, the coefficients of the other two bilateral characteristics' variables, such as difference GDP per capita and distance, remain negative and insignificant. Control variables such as GDP per capita, the size of the population, and the infrastructure show a positive and significant effect and signify that the growth in the market size increases host countries' inward FDI. This finding is consistent with the existing literature (Aziz 2018; Kahouli and Maktouf 2015). However, the coefficient of resource endowment and inflation is negative and significant. This implies that the massive potential of natural resources can cost the 'resource curse' issue (Asiedu 2013), and a higher rate of inflation means higher uncertainties for the foreign investors (Aziz 2018). However, the coefficient of trade gives an insignificant value to influence the bilateral FDI in G20 countries.

Model 3 reveals that the coefficient of $\mathrm{CO}_{2}$ emission intensity reveals a positive and significant effect on institutional quality in G20 countries. This implies that higher emission countries with increased production and energy consumption can boost economic growth and improve institutional performance. This study also remains consistent with the existing literature (Hosseini and Kaneko 2013). The coefficient of the bilateral FDI has a positive and significant effect on institutional quality. This implies that more and more FDI can promote better institutional quality in the host destination. This result is consistent with the existing literature (Huynh 2020; Huynh et al. 2020). Simultaneously, the lagged value of institutional quality reveals a positive and significant effect on institutional quality. The coefficient of the difference in carbon emission intensity and the difference in GDP per capita has a negative and significant impact on institutional quality. This implies that the differences in environmental quality and economic growth among pair countries also influence the host countries' institutional quality. However, the 
541 coefficient of the difference in institutional quality remains positive and significant. The other important explanatory

542 variables, such as GDP per capita, demonstrate a positive and significant impact on institutional quality. The

543 coefficients of population, resource endowments, financial development, and inflation reveal a negative and

544 significant effect on the source countries' institutional quality. However, the coefficient value of trade openness and

545 infrastructure remains insignificant to influence the institutional quality in our findings.

[Insert Table 5 near here]

547 In summary, our empirical results confirm that bilateral FDI improves environmental quality by reducing $\mathrm{CO}_{2}$ 548 emission intensity in G20. Thus our result supports the existence of the 'halo effect' in our sample countries. Next, 549 our empirical estimation confirms that the institutional quality and $\mathrm{CO}_{2}$ emission intensity has significantly caused 550 each other in G20. The result also reports a significant bidirectional association between institutional quality and 551 bilateral FDI. Finally, with system estimators' help, our results confirm the final hypothesis of this paper and 552 evidence a simultaneous relationship between $\mathrm{CO}_{2}$ emission intensity, bilateral FDI, and institutional quality in G20. 553 Our empirical results prioritize a trilateral relationship among $\mathrm{CO}_{2}$ emission intensity, bilateral FDI, and institutional 554 quality (see Fig. 1). However, our results confirm only a unidirectional positive relationship between FDI and 555 environmental quality in G20. With this, our findings imply significant policy implications to achieve sustainable growth concerning environment-FDI-institution nexus for G20 economies.

[Insert Figure 1 near here]

\section{Conclusion}

Over the last few years, environmental quality, bilateral FDI, and institutional quality research have been focal topics. However, hardly any study considered the relationship between environmental quality, bilateral inward FDI, and institutions on each other in 19 selected G20 countries during the sample period of 2009-2017. Our research uses a panel of 342 pairs of host and source countries by using three basic panel estimators such as fixed effect, random effect, and Hausman-Taylor estimators to demonstrate a preliminary result of our hypothesis. However, to overcome the limitations of static one equation models, we follow three simultaneous techniques: seeming unrelated regression, three-stage least square, and the system generalized method of moments estimators. The lagged value of three dependent variables in the SGMM reveals a significant agglomeration effect in each case. Our research indicates that bilateral FDI directly influences $\mathrm{CO}_{2}$ emission intensity, implying that FDI helps the G20 countries to improve environmental quality. The results support that the host countries' institutional quality has positive and significant encouragement to FDI. Simultaneously, the results support that the bilateral FDI also improves host countries' institutional quality in the sample case. The findings reveal that institutional quality and $\mathrm{CO}_{2}$ emission intensity are simultaneously associated in host countries. The result shows bilateral characteristic variables like distance, the difference in institutional quality, the difference in $\mathrm{CO}_{2}$ emission intensity, and the difference in per capita GDP play an essential role in determining the source countries' environmental quality, institutional

574 performance, and bilateral FDI stocks. In addition to these, our findings also reveal that other macro-economic 575 variables such as GDP per capita, size of the population, financial development, trade openness, infrastructure, 
natural resources, inflation, human capital, and urbanization are significant to influence the environment-FDIinstitution nexus in selected G20 countries.

578 Our study has few limitations; first, we have ignored the interaction effect of bilateral $\mathrm{FDI}_{\text {and }} \mathrm{CO}_{2}$ emission intensity on institutional quality, bilateral FDI and institutional quality on $\mathrm{CO}_{2}$ emission intensity, and institutional quality and $\mathrm{CO}_{2}$ emission intensity on FDI. Second, our study is limited to only select 19 countries of G20 economies. Third, our study is limited to only nine years due to data limitations. Thus we suggest that further research can extend this study taking the interaction effect into the linkage. Studies can be broadened to cover the entire world using various econometric specifications.

\section{Policy implication}

This study suggests the subsequent policy implications of G20 countries to decrease the environmental degradation and a better economy with improved institutional quality and a large volume of foreign investments. The policymakers should encourage more greener FDI in G20 countries with incentive policies such as tax reductions and more subsidies. This is because it helps to use more advanced technologies and clean energy-efficient technologies to reduce the emission pressure to have a better economy. The government of G20 economies should allow other countries' investment to boost up their institutional reforms to achieve a sustainable economy. However, G20 economies should minimize performance gaps in all three aspects to maximize benefits from FDI while also improving institutions and maintaining a pollution-free environment.

Further, the study suggests policymakers should invest more to provide advanced equipment to extractive units during the extraction of natural resources to curb the negative impact of natural resources on environment quality in sample countries. However, G20 economies should promote urbanization and invest more in human capital to achieve a low level of pollution in their economies. Our research also finds that G20 countries' governments should consider the impact of other macroeconomic factors such as GDP, infrastructure, and population while making any policy framework concerning environment-FDI-institution nexus. Here, economies should emphasize avoiding a trade-off between economic growth and environmental quality by relaxing rules to attract greater FDI inflows, strengthening institutions, and improving environmental quality. Therefore G20 economies have to follow a comprehensive framework to achieve the sustainable goals 2030 with a multidimensional process with high 602 integrity.

\section{Declaration}

604 Ethics approval and consent to participate: The authors declare the provided manuscript with the title "Integrated 605 Analysis of $\mathrm{CO}_{2}$ Emission Intensity, Bilateral FDI, and Institutional Quality Nexus: Case Study of G20 Countries”

606 has not been published before nor submitted to another journal for the consideration of publication.

607 Consent for publication: The authors declare that the manuscript does not contain any person's data in any form 608 (including any individual details, images, or videos). 
Availability of data and materials: The original data sources of this article are presented at the last of the references with the URLs. However, the datasets generated during and analyzed during the current study are remained confidential but may be available upon reasonable request from the corresponding author.

Funding: This research received no specific grant from any funding agency in the public, commercial, or not-forprofit sectors.

Authors' contribution: Prajukta Tripathy: Writing-original draft, Data Analysis, Methodology, Econometric Estimation using STATA Software; Monalisa Khatua: Methodology, Data curation, Estimation; Pragyarani Behera: Data compilation, software handling; Lopamudra D. Satpathy: Writing-reviewing, Structural Editing; Pabitra Kumar Jena: Writing-reviewing, Editing; Bikash Ranjan Mishra: Conceptualization, Methodology, Estimation, Supervision, Writing-reviewing, Editing.

Authors' information: Prajukta Tripathy is a Ph.D. scholar in Economics at the Department of Humanities and Social Sciences, NIT Rourkela, Odisha. She received her M.Phil. degree from the School of Economics, Central University of Hyderabad, Telangana. She completed her Post graduation in economics from the Department of Analytical and Applied Economics, Utkal University, Odisha. Her research interest focuses on environmental economics, energy economics, international economics, industrial economics, and econometrics. She has been published research papers in reputed international journals.

Monalisa Khatua is a Ph.D. scholar in Economics at the Department of Humanities and Social Sciences, NIT Rourkela, Odisha. She received her bachelor of arts in economics from Ravenshaw University, Cuttack, Odisha, and her master of arts in economics from the School of Economics, Central University of Hyderabad, Telangana. Her research areas of interest focus on migration, international economics, and econometrics.

Pragyanrani Behera is a Ph.D. scholar in economics at the Department of Humanities and Social Sciences, NIT Rourkela. She received her M.Phil. degree from Berhampur University. Her research interest is in international economics and econometrics. She has been published research papers in reputed international journals.

Dr. Lopamudra D. Satpathy is currently working as the Assistant Professor in Economics, being appointed under Odisha Education Service (Group-I), Odisha Public Service Commission, Department of Higher Education, Government of Odisha. She is currently heading her department being posted as Head of the Department of Economics, Sushilavati Government Women's College, Rourkela, Odisha. Soon after her Master's degree in Economics from Hyderabad Central University and M. Phil from Utkal University, she obtained her Doctorate degree in Economics from HSS Department of IIT, Kharagpur with specialization in Productivity analysis, Industrial Organization and International Economics. She has a couple of publications in international journals such as Margin: The Journal of Applied Economic Research, Journal of Management Research, South Asia Economic Journal and International Journal of Economics and Business Administration.

Dr. Pabitra Kumar Jena, Alumni of the University of Hyderabad and National Institute of Industrial Engineering (NITIE), Mumbai, is an Assistant Professor in Economics at the School of Economics, Faculty of Management, Shri Mata Vaishno Devi University, Katra, Jammu \& Kashmir. Teaching and research interests of Dr. Jena include 
International Economics, Quantitative Techniques, Applied Econometrics, Modeling with R, Macroeconomic

646 Modeling, Health Economics, and Managerial Economics. Apart from academic research, he also contributes to

647 different English Dailies on contemporary socio-economic issues. He has successfully conducted several

648 Conferences (International \& National), Seminars, symposiums, Faculty Development Programmes, and Research

649 Workshops. His publications include 3 Books and 30 Research Papers in various reputed Journals such as

650 Environmental Science and Pollution Research, Journal of Economic Studies, International Journal of Health Care

651 Quality Assurance, Women's Health Reports, Copernican Journal of Finance \& Accounting, The Indian Journal of

652 Economics, Productivity and Journal of Tourism.

653 Dr. Bikash Ranjan Mishra is currently working as the Assistant Professor in Economics, Department of Humanities

654 and Social Sciences, National Institute of Technology (NIT), Rourkela, Odisha. After completion of his Master's

655 degree in Economics, he obtained his Ph.D. in Economics from IIT, Kanpur, with specialization in Industrial

656 Organization and International Trade and Investment. He has almost 11 years of Teaching and Research experience.

657 He has a couple of publications in international journals such as International Journal of Finance and Economics,

658 Emerging Market Finance and Trade, Journal of Economic Studies, International Journal of Social Economics,

659 South Asia Economic Journal, Journal of Public Affairs, Theoretical and Applied Economics, Taylor's Business

660 Review and IUP Applied Economics.

661

662 Competing interests: The authors declare that there is no conflict of interest regarding the publication of this paper.

663

664

665

666

667

668

669

670

671

672

673

674 
676 Abdouli, M., Kamoun, O., Hamdi, B (2018) The impact of economic growth, population density, and FDI inflows

677 on $\mathrm{CO}_{2}$ emissions in BRICS countries: Does the Kuznets curve exist?.Empirical Economics, 54(4), 1717-1742.

678 https://doi.org/10.1007/s00181-017-1263-0

679 Acharyya, J (2009) FDI, growth and the environment: Evidence from India on $\mathrm{CO}_{2}$ emission during the last two 680 decades. Journal of Economic Development, 34(1), 43.

681 Acheampong, A. O., Adams, S., Boateng, E (2019) Do globalization and renewable energy contribute to carbon 682 emissions mitigation in Sub-Saharan Africa?. Science of the Total Environment,677, 436-446. 683 https://doi.org/10.1016/j.scitotenv.2019.04.353

684 Adeola, F. O (2000) Cross-national environmental injustice and human rights issues: A review of evidence in the 685 developing world. American Behavioral Scientist, 43(4), 686-706. https://doi.org/10.1177/00027640021955496

686 Ali, H. S., Zeqiraj, V., Lin, W. L., Law, S. H., Yusop, Z., Bare, U. A. A., Chin, L (2019) Does quality institutions 687 promote environmental quality?. Environmental Science and Pollution Research, 26(11), 10446-10456. 688 https://doi.org/10.1007/s11356-019-04670-9

689 Arminen, H., Menegaki, A. N (2019) Corruption, climate and the energy-environment-growth nexus. Energy 690 Economics, 80, 621-634. https://doi.org/10.1016/j.eneco.2019.02.009

691 Armitage, D., De Loë, R., Plummer, R (2012) Environmental governance and its implications for conservation 692 practice. Conservation Letters, 5(4), 245-255. https://doi.org/10.1111/j.1755-263X.2012.00238.X

693 Asiedu, E (2013) Foreign direct investment, natural resources and institutions. International Growth 694 Centre, Working paper. 1-38. https://doi.org/10.1371/journal.pone.0215650

695 Azam, M (2016) Does environmental degradation shackle economic growth? A panel data investigation on 11 Asian 696 countries. Renewable and Sustainable Energy Reviews, 65, 175-182. https://doi.org/10.1016/j.rser.2016.06.087

697 Azam, M., Liu, L., Ahmad, N (2021) Impact of institutional quality on environment and energy consumption: 698 evidence from developing world. Environment, Development and Sustainability, 23(2), 1646-1667. 699 https://doi.org/10.1007/s10668-020-00644-x

700 Aziz, O. G (2018) Institutional quality and FDI inflows in Arab economies. Finance Research Letters, 25, 111-123. 701 https://doi.org/10.1016/j.frl.2017.10.026 

experience. Structural Change and Economic Dynamics, 51, 119-125. https://doi.org/10.1016/j.strueco.2019.08.007 haven and pollution halo hypotheses in MINT countries. Environmental Science and Pollution Research, 26(22), 23010-23026. https://doi.org/10.1007/s11356-019-05446-x

Baltagi B (2008) Econometric analysis of panel data. John Wiley \& Sons.

Bokpin, G. A (2017) Foreign direct investment and environmental sustainability in Africa: The role of institutions and governance. Research in International Business and Finance, 39, 239-247.

710 https://doi.org/10.1016/j.ribaf.2016.07.038

711 Copeland, B. R., Taylor, M. S (1994) North-South trade and the environment. The quarterly journal of 712 Economics, 109(3), 755-787. https://doi.org/10.2307/2118421

713 Dang, P. T (2019) Sustainability comes from within: carbon dioxide emissions, FDI origin factor and institutional 714 qualities in developing countries. Economia Politica, 36(2), 439-471. https://doi.org/10.1007/s40888-019-00151-x

715 Daude, C., Stein, E (2007) The quality of institutions and foreign direct investment. Economics \& Politics, 19(3), 716 317-344. https://doi.org/10.1111/j.1468-0343.2007.00318.x

717 Donaubauer, J., Neumayer, E., Nunnenkamp, P (2020) Financial market development in host and source countries

718 and their effects on bilateral foreign direct investment. The World Economy, 43(3), 534-556. 719 https://doi.org/10.1111/twec.12884

720 Dong, K., Dong, X., Dong, C (2019) Determinants of the global and regional $\mathrm{CO}_{2}$ emissions: what causes what and 721 where?. Applied Economics, 51(46), 5031-5044. https://doi.org/10.1080/00036846.2019.1606410

722 Dunning, J. H (1980) Toward an eclectic theory of international production: Some empirical tests. Journal of 723 International Business Studies, 11(1), 9-31. https://doi.org/10.1057/palgrave.jibs.8490593

724 Essandoh, O. K., Islam, M., Kakinaka, M (2020) Linking international trade and foreign direct investment to $\mathrm{CO}_{2}$ 725 emissions: any differences between developed and developing countries?. Science of the Total Environment, 712, 1726 10. https://doi.org/10.1016/j.scitotenv.2019.136437

727 Fukumi, A., Nishijima, S (2010) Institutional quality and foreign direct investment in Latin America and the 728 Caribbean. Applied Economics, 42(14), 1857-1864. https://doi.org/10.1080/00036840701748979 
729 Grossman, G. M., Krueger, A. B (1991) Environmental impacts of a North American free trade agreement. National 730 Bureau of Economic Research. DOI 10.3386/w3914. (https://www.nber.org/papers/w3914) (Accessed on 30 April $7312020)$

732 Gujarati D (2004) Basic Econometrics Fourth (4th) Edition. Magraw Hill Inc, New York.

733 Hargrove, A., Qandeel, M., Sommer, J. M (2019) Global governance for climate justice: A cross-national analysis of $734 \mathrm{CO}_{2}$ emissions. Global Transitions, 1, 190-199. https://doi.org/10.1016/j.glt.2019.11.001

735 Haug, A. A., Ucal, M (2019) The role of trade and FDI for $\mathrm{CO}_{2}$ emissions in Turkey: Nonlinear 736 relationships. Energy Economics, 81, 297-307. https://doi.org/10.1016/j.eneco.2019.04.006

737 Hausman, J. A., Taylor, W. E (1981) Panel data and unobservable individual effects. Econometrica: Journal of the 738 Econometric Society, 1377-1398. https://doi.org/10.2307/1911406

739 Hosseini, H. M., Kaneko, S (2013) Can environmental quality spread through institutions?. Energy Policy, 56, 312740 321. https://doi.org/10.1016/j.enpol.2012.12.067

741 Huynh, C. M (2020) How does the impact of foreign direct investment on institutional quality depend on the 742 underground economy?.Journal of Sustainable Finance \& Investment. 10 (4), 1-16. 743 https://doi.org/10.1080/20430795.2020.1788851

744 Huynh, C. M., Nguyen, V. H. T., Nguyen, H. B., Nguyen, P. C (2020) One-way effect or multiple-way causality: 745 foreign direct investment, institutional quality and shadow economy?. International Economics and Economic 746 Policy, 17(1), 219-239. https://doi.org/10.1007/s10368-019-00454-1

747 Ibrahim, O. A., Devesh, S., Shaukat, M (2020) Institutional determinants of FDI in Oman: Causality analysis 748 framework. International Journal of Finance \& Economics. 25(4), 1-13. https://doi.org/10.1002/ijfe.2366

749 Intergovernmental Panel on Climate Change (IPCC) (2014) Climate change https://www.ipcc.ch/report/ar5/syr/ 750 (Accessed 18 January 2021)

751 International Monetary Fund (2017) "World Economic Outlook Database: GDP per capita, GDP PPP, GDP PPP per 752 capita, Population for G20 countries (Sans EU)". International Monetary Fund, April. 753 https://www.imf.org/en/Publications/SPROLLs/world-economic-outlook-

754 databases\#sort=\%40imfdate\%20descending (Accessed $2^{\text {nd }}$ January 2021) 
755

756

757

758

759

760

761

762

763

764

765

766

767

768

769

770

771

772

773

774

775

776

777

778

779

780

781

782

783

Jorgenson, A. K (2009) Foreign direct investment and the environment, the mitigating influence of institutional and civil society factors, and relationships between industrial pollution and human health: A panel study of lessdeveloped countries. Organization \& Environment, 22(2), 135-157. https://doi.org/10.1177/1086026609338163

Jun, W., Zakaria, M., Shahzad, S. J. H., Mahmood, H (2018) Effect of FDI on pollution in China: New insights based on wavelet approach. Sustainability, 10(11), 3859. https://doi.org/10.3390/su10113859

Kahouli, B (2018) The causality link between energy electricity consumption, $\mathrm{CO}_{2}$ emissions, $\mathrm{R} \& \mathrm{D}$ stocks and $\begin{array}{lllll}\text { economic growth in } & \text { Mediterranean } & \text { countries } & \text { (MCs). Energy, 145, }\end{array}$ https://doi.org/10.1016/j.energy.2017.12.136

Kahouli, B., Maktouf, S (2015) The determinants of FDI and the impact of the economic crisis on the implementation of RTAs: A static and dynamic gravity model. International Business Review, 24(3), 518-529. https://doi.org/10.1016/j.ibusrev.2014.10.009

Kahouli, B., Omri, A (2017) Foreign direct investment, foreign trade and environment: New evidence from simultaneous-equation system of gravity models. Research in International Business and Finance, 42, 353-364. https://doi.org/10.1016/j.ribaf.2017.07.161

Kandil, M (2009) Determinants of institutional quality and their impact on economic growth in the MENA region. International Journal of Development Issues. 8(2), 134-167. https://doi.org/10.1108/14468950910997693

Khan, M. A., Ozturk, I (2020) Examining foreign direct investment and environmental pollution linkage in Asia. Environmental Science and Pollution Research, 27(7), 7244-7255. https://doi.org/10.1007/s11356-019-07387$\underline{x}$

Khan, M. K., Teng, J. Z., Khan, M. I., Khan, M. O (2019) Impact of globalization, economic factors and energy consumption on $\mathrm{CO}_{2}$ emissions in Pakistan. Science of the Total Environment, 688, 424-436. https://doi.org/10.1016/j.scitotenv.2019.06.065

Khan, M., Hanif, W (2020) Institutional quality and the relationship between inflation and economic growth. Empirical Economics, 58(2), 627-649. https://doi.org/10.1007/s00181-018-1479-7

Kunčič A (2014) Institutional quality dataset. Journal of Institutional Economics. 10(1):135-61. https://doi.org/10.1017/S1744137413000192

Kunčič, A., Jaklič, A (2014) FDI and institutions: Formal and informal institutions. In Multinational Enterprises, Markets and Institutional Diversity. Emerald Group Publishing Limited. (Progress in International Business Research. 9, 171-205. https://doi.org/10.1108/S1745-886220140000009007 
784 Kurul, Z., Yalta, A. Y (2017) Relationship between institutional factors and FDI flows in developing countries: New 785 evidence from dynamic panel estimation. Economies, 5(2), 17. https://doi.org/10.3390/economies5020017

786 Le, H. P., Ozturk, I (2020) The impacts of globalization, financial development, government expenditures, and 787 institutional quality on $\mathrm{CO}_{2}$ emissions in the presence of environmental Kuznets curve. Environmental Science and 788 Pollution Research, 27(18), 22680-22697. https://doi.org/10.1007/s11356-020-08812-2

789 Lemprière, M (2016) Using ecological modernisation theory to account for the evolution of the zero-carbon homes 790 agenda in England. Environmental Politics, 25(4), 690-708. https://doi.org/10.1080/09644016.2016.1156107

791 Li, K., Hu, E., Xu, C., Musah, M., Kong, Y., Mensah, I. A., Su, Y (2021) A heterogeneous analysis of the nexus 792 between energy consumption, economic growth and carbon emissions: Evidence from the group of twenty (G20) 793 countries. Energy Exploration \& Exploitation, 39(3), 815-837. https://doi.org/10.1177/0144598720980198

794 Mahjabeen N, Shah, S. Z., Chughtai, S., Simonetti, B (2020) Renewable energy, institutional stability, environment 795 and economic growth nexus of D-8 countries. Energy Strategy Reviews, 29 , 100484. 796 https://doi.org/10.1016/j.esr.2020.100484

797 Mardani, A., Streimikiene, D., Nilashi, M., Arias Aranda, D., Loganathan, N., Jusoh, A (2018) Energy consumption, 798 economic growth, and $\mathrm{CO}_{2}$ emissions in $\mathrm{G} 20$ countries: application of adaptive neuro-fuzzy inference 799 system. Energies, 11(10), 1-15. https://doi.org/10.3390/en11102771

800 Marques, A. C., Caetano, R (2020) The impact of foreign direct investment on emission reduction targets: Evidence 801 from high-and middle-income countries. Structural Change and Economic Dynamics,55, 107-118. 802 https://doi.org/10.1016/j.strueco.2020.08.005

803 Mielnik, O., Goldemberg, J (2002) Foreign direct investment and decoupling between energy and gross domestic 804 product in developing countries. Energy policy, 30(2), 87-89. https://doi.org/10.1016/S0301-4215(01)00080-5

805 Mishra, B. R., Jena, P. K (2019) Bilateral FDI flows in four major Asian economies: a gravity model 806 analysis. Journal of Economic Studies. 46(1), 71-89. https://doi.org/10.1108/JES-07-2017-0169

807 Mol, A. P., Spaargaren, G (2000) Ecological modernisation theory in debate: A review. Environmental politics, 9(1), 808 17-49. https://doi.org/10.1080/09644010008414511

809 Moon, C (2019) Political institutions and FDI inflows in autocratic countries. Democratization, 26(7), $1256-1277$. 810 https://doi.org/10.1080/13510347.2019.1627520 
811 Muhammad, B (2019) Energy consumption, $\mathrm{CO}_{2}$ emissions and economic growth in developed, emerging and

812 Middle East and North Africa countries. Energy, 179, 232-245. https://doi.org/10.1016/j.energy.2019.03.126

813 Muhammad, B., Khan, S (2019) Effect of bilateral FDI, energy consumption, $\mathrm{CO}_{2}$ emission and capital on economic

814 growth of Asia countries. Energy Reports, 5, 1305-1315. https://doi.org/10.1016/j.egyr.2019.09.004

815 Muhammad, S., Long, X., Salman, M., Dauda, L (2020) Effect of urbanization and international trade on $\mathrm{CO}_{2}$

816 emissions across 65 belt and road initiative countries. Energy, 196. https://doi.org/10.1016/j.energy.2020.117102

817 North DC (1990) Institutions, institutional change and economic performance. Cambridge university press.

818 https://doi.org/10.1017/CBO9780511808678

819 Omri, A., Mabrouk, N. B (2020) Good governance for sustainable development goals: Getting ahead of the pack or 820 falling behind? Environmental Impact Assessment Review, 83, 1-8. https://doi.org/10.1016/j.eiar.2020.106388

821 Omri, A., Nguyen, D. K., Rault, C (2014) Causal interactions between $\mathrm{CO}_{2}$ emissions, FDI, and economic growth:

822 Evidence from dynamic simultaneous-equation models. Economic Modelling, 42, 382-389.

823 https://doi.org/10.1016/j.econmod.2014.07.026

824 Opoku, E. E. O., Boachie, M. K (2020) The environmental impact of industrialization and foreign direct 825 investment. Energy Policy, 137, 1-12. https://doi.org/10.1016/j.enpol.2019.111178

826 Pao, H. T., Tsai, C. M (2011) Multivariate Granger causality between $\mathrm{CO}_{2}$ emissions, energy consumption, FDI 827 (foreign direct investment) and GDP (gross domestic product): evidence from a panel of BRIC (Brazil, Russian 828 Federation, India, and China) countries. Energy, 36(1), 685-693. https://doi.org/10.1016/j.energy.2010.09.041

829 Paramati, S. R., Apergis, N., Ummalla, M (2017) Financing clean energy projects through domestic and foreign 830 capital: The role of political cooperation among the EU, the G20 and OECD countries. Energy Economics, 61, 62-

831 71. https://doi.org/10.1016/j.eneco.2016.11.001

832 Pazienza, $\mathrm{P}$ (2015) The relationship between $\mathrm{CO}_{2}$ and Foreign Direct Investment in the agriculture and fishing sector 833 of OECD countries: Evidence and policy considerations. Intelektine Ekonomika, 9(1), 55-66. 834 https://doi.org/10.1016/j.intele.2015.08.001

835 Peres, M., Ameer, W., Xu, H (2018) The impact of institutional quality on foreign direct investment inflows: 836 evidence for developed and developing countries. Economic research-Ekonomska Istraživanja, 31(1), 626-644. 837 https://doi.org/10.1080/1331677X.2018.1438906 
838 Pethig, R (1976) Pollution, welfare, and environmental policy in the theory of comparative advantage. Journal of

839 Environmental Economics and Management, 2(3), 160-169. https://doi.org/10.1016/0095-0696(76)90031-0

840 Porter, M. E., Van der Linde, C (1995) Toward a new conception of the environment-competitiveness

841 relationship. Journal of Economic Perspectives, 9(4), 97-118. DOI: 10.1257/jep.9.4.97

842 Roodman, D (2009) How to do xtabond2: An introduction to difference and system GMM in Stata. The Stata

843 Journal, 9(1), 86-136. https://doi.org/10.1177/1536867X0900900106

844 Rudolph, A., Figge, L (2017) Determinants of ecological footprints: what is the role of globalization?. Ecological

845 Indicators, 81, 348-361. https://doi.org/10.1016/j.ecolind.2017.04.060

846 Sabir, S., Qayyum, U., Majeed, T (2020) FDI and environmental degradation: the role of political institutions in

847 South Asian countries. Environmental Science and Pollution Research. 27(26), 32544-32553.

848 https://doi.org/10.1007/s11356-020-09464-y

849 Sabir, S., Rafique, A., Abbas, K (2019) Institutions and FDI: evidence from developed and developing

850 countries. Financial Innovation, 5(1), 1-20. https://doi.org/10.1186/s40854-019-0123-7

851 Saidi, H., El Montasser, G., Ajmi, A. N (2020) The role of institutions in the renewable energy-growth nexus in the

852 MENA region: a panel cointegration approach. Environmental Modeling \& Assessment, 25(2), 259-276.

853 https://doi.org/10.1007/s10666-019-09672-y

854 Salahuddin, M., Alam, K., Ozturk, I., Sohag, K (2018) The effects of electricity consumption, economic growth, 855 financial development and foreign direct investment on $\mathrm{CO}_{2}$ emissions in Kuwait. Renewable and Sustainable

856 Energy Reviews, 81, 2002-2010. https://doi.org/10.1016/j.rser.2017.06.009

857 Scruggs, L., Rivera, C (2008) Political regimes, democratic institutions and environmental sustainability: A cross858 national analysis. In Proceedings of the Midwest Political Science Association Meeting in Chicago, Chicago, IL, 859 USA. 36, 1-39.

860 Shahbaz, M., Nasreen, S., Abbas, F., Anis, O (2015) Does foreign direct investment impede environmental quality 861 in high-, middle-, and low-income countries? Energy Economics, 51, 275-287.

$862 \quad$ https://doi.org/10.1016/j.eneco.2015.06.014

863 Tang, D., Li, S., Yang, Y., Gu, L (2020) Regional difference in spatial effects: A theoretical and empirical study on 864 the environmental effects of FDI and corruption in China. Discrete Dynamics in Nature and 865 Society, https://doi.org/10.1155/2020/8654817 
866 Ullah, I., Khan, M. A (2017) Institutional quality and foreign direct investment inflows: evidence from Asian 867 countries. Journal of Economic Studies. 44(6), 1030-1050. https://doi.org/10.1108/JES-10-2016-0215

868 United Nations (2019) The Sustainable Development Goals Report.

869 https://www.un.org/development/desa/publications/sustainable-development-goals-report-2019.html (Accessed 18

870 January 2021)

871 Walter, I., Ugelow, J. L (1979) Environmental policies in developing countries. Ambio, 102-109.

872 https://doi.org/10.4236/oalib.1100869

873 Wang, N., Zhu, H., Guo, Y., Peng, C (2018) The heterogeneous effect of democracy, political globalization, and

874 urbanization on PM2. 5 concentrations in G20 countries: Evidence from panel quantile regression. Journal of

875 Cleaner Production, 194, 54-68. https://doi.org/10.1016/j.jclepro.2018.05.092

876 Wang, S., Wang, H., Sun, Q (2020) The Impact of Foreign Direct Investment on Environmental Pollution in China:

877 Corruption Matters. International Journal of Environmental Research and Public Health, 17(18), 1-20.

878 https://doi.org/10.3390/ijerph17186477

879 Wang, Z., Zhang, B., Wang, B (2018) The moderating role of corruption between economic growth and $\mathrm{CO}_{2}$

880 emissions: evidence from BRICS economies. Energy, 148, 506-513.

881 Westney, D.E (1993) Institutionalization Theory and the Multinational Corporation. In: Ghoshal S., Westney,D.E. 882 (eds) Organization Theory and the Multinational Corporation. Palgrave Macmillan, London. 883 https://doi.org/10.1007/978-1-349-22557-6_3

884 Wooldridge JM (2010) Econometric analysis of cross section and panel data. MIT press.

885 Wooldridge JM (2016) Introductory econometrics: A modern approach. Nelson Education.

886 World Bank (2020) World Development Indicators.

887 https://databank.worldbank.org/reports.aspx?source=World-Development-Indicators (Accessed on $1^{\text {st }}$ August 2020)

888 Wu, W. L (2017) Institutional Quality and Air Pollution: International Evidence. International Journal of Business 889 \& Economics, 16(1), 49-74.

890 Xu, B., Zhong, R., Qiao, $\mathrm{H}$ (2020) The impact of biofuel consumption on $\mathrm{CO}_{2}$ emissions: A panel data analysis for 891 seven selected G20 countries. Energy $\quad$ \& $\quad$ Environment, 31(8), $1498-1514$. 892 https://doi.org/10.1177/0958305X20915426 
893 Yao, X., Kou, D., Shao, S., Li, X., Wang, W., Zhang, C (2018) Can urbanization process and carbon emission 894 abatement be harmonious? New evidence from China. Environmental Impact Assessment Review, 71, 70-83. 895 https://doi.org/10.1016/j.eiar.2018.04.005

896 Yao, X., Tang, X (2021) Does financial structure affect CO2 emissions? Evidence from G20 countries. Finance 897 Research Letters, 41, 1-26. https://doi.org/10.1016/j.frl.2020.101791

898 Zarsky, L (1999) Havens, halos and spaghetti: untangling the evidence about foreign direct investment and the 899 environment. Foreign Direct Investment and the Environment, 13(8), 47-74.

900 Zellner A, Theil H (1962) Three-Stage Least Squares: Simultaneous Estimation of Simultaneous Equations. 901 Econometrica: Journal of the Econometric Society. 30(1):54-78. https://doi.org/10.2307/1911287 


\section{Figures}

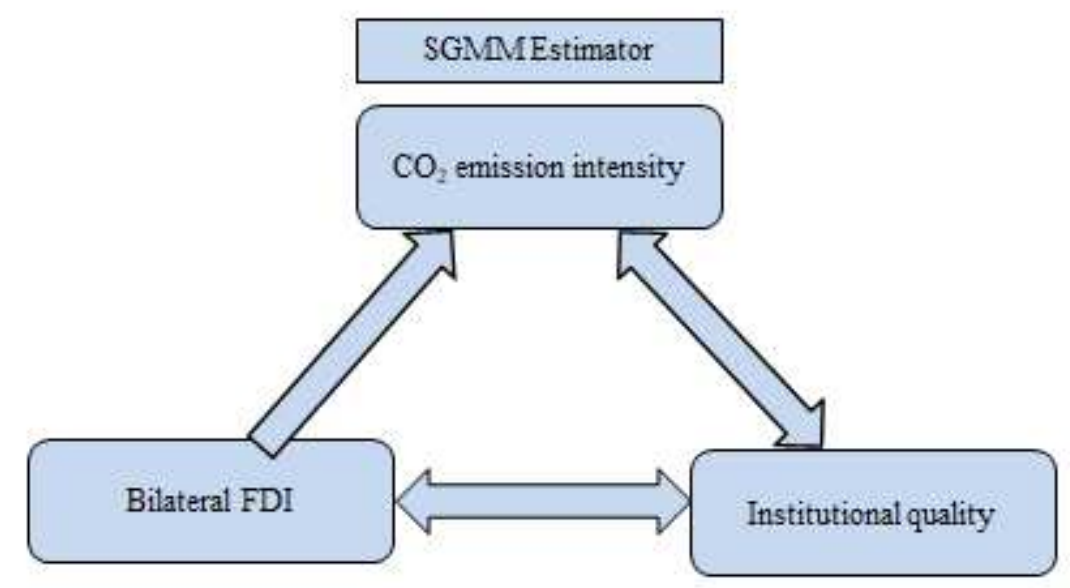

\section{Figure 1}

The three-way linkage for selected G20 countries Note: This three-way linkage of the SGMM estimator is consistent with the SUR and the 3SLS results. Source: Authors' calculation

\section{Supplementary Files}

This is a list of supplementary files associated with this preprint. Click to download.

- Supplementarymaterial.docx 